E3S Web of Conferences 1, 15003 (2013)

DOI: $10.1051 / \mathrm{e} 3$ sconf/20130115003

(c) Owned by the authors, published by EDP Sciences, 2013

\title{
The content of lead in some organs and tissues of Hereford bull-calves
}

\author{
K. N. Narozhnyh ${ }^{1}$, Y. V. Efanova ${ }^{1}$, V. L. Petukhov ${ }^{1}$, O. S. Korotkevich ${ }^{1}$, B. A. Skukovsky ${ }^{1}$ and G. N. Korotkova ${ }^{1}$ \\ ${ }^{1}$ Novosibirsk State Agrarian University,160 Dobrolubov Str., Novosibirsk 630039, Russia, vpetukhov@ngs.ru
}

\begin{abstract}
The content of lead in muscles, liver, spleen and testicles is studied in Hereford bulls, aged 18 months. Selectivity of $\mathrm{Pb}$ accumulation is identified in organs and tissues. $\mathrm{Pb}$ level in organs and tissues may be ranged as follows: liver $>$ spleen $>$ muscles $>$ testicles in the ratio 4.7: 4.4: 1.2: 1 . It is shown that the increased concentration of lead in testicles decreases the content of vitamins. Some biological indexes of blood serum are indicators of $\mathrm{Pb}$ level in muscles and liver.
\end{abstract}

Key words: Bulls, content of lead, muscles, liver, spleen, testicles.

\section{Introduction}

The biological role of lead has not been sufficiently studied. Animals experience the deficiency of the element when its concentration in feeds is under $0.05-0.5 \mathrm{mg} / \mathrm{kg}$. Under this condition, metabolism of iron fails as well as does the effect of some enzymes and concentration of separate metabolites in liver that are associated with $\mathrm{Fe}$ status [1.2].

Major ways for lead to enter human organism from the objects of environment are inhalation and enteric. The inhalation way is inhaling it together with the inhaled air. The enteric one is lead incorporated in drinking water and food [3. 4]. Most metals, from 44 to $100 \%$, enter the organism combined with food through gastrointestinal tract. About 0.01-0.024 mg/day of the metals enter the organism with drinking water.

The toxic effect of lead is largely determined by its capacity to form relations to a great many anions-ligands, to which refer sulfhydric groups, cysteine derivatives, imidazole and carboxyl groups, phosphates [5]. The binding of anhydrines to lead results in inhibited protein synthesis and enzymatic activity eg., ATP-ase. Lead disturbs hem and globin synthesis, affects porphyrin exchange, induces defects of erythrocyte membranes, decreases antibody genesis [6. 7]. Continuous accumulation of lead may cause the formation of eosinophilic inclusions inside a nucleus [8]. Heavy metals are shown to get accumulated in animal organs and tissues at different levels in different ecological zones [9].

\section{Materials and Methods}

The study was carried out on the basis of the laboratory of Siberian Institute of Livestock Breeding. The object to examine was Hereford bull-calves, aged 16-18 months. The subject to examine was liver, muscles, kidneys and testicles of the bull-calves. The bull-calves were raised on the farm "Tayezhnoye" of Novosibirsk region in an ecologically friendly zone. All the animals were healthy at slaughter time. 40 samples from the tissue of the organs were taken to examine. The concentration of heavy metals in the air-dry substance was determined with the atomic absorption method.

The data obtained were treated with the method of variation statistic and PC software Microsoft Excel.

\section{Results and Discussion}

The data on $\mathrm{Pb}$ content in the organs and tissues of the Hereford bull-calves are presented in Table 1 . Considerable differences between separate animals were revealed for the capacity to accumulate lead in liver (in the ratio 1:5.8) and muscles (1:5.4). $\mathrm{Pb}$ level is characterized by high phenotypic variability particularly in liver and muscle.

Table 1. Pb content in muscles and testicles, $\mathrm{mg} / \mathrm{kg}$

\begin{tabular}{|l|c|c|c|c|}
\hline $\begin{array}{c}\text { Organ } \\
\text { tissue } \\
\end{array}$ & $\begin{array}{c}\text { 日 } \\
\pm \mathrm{ME}\end{array}$ & $\mathrm{S}$ & $\mathrm{C} . \mathrm{V}$. & $\lim$ \\
\hline Muscles & $\begin{array}{c}0.038 \pm \\
0.007\end{array}$ & 0.022 & 57.0 & $0.017-$ \\
& & & 0.093 \\
Testicles & $0.032 \pm$ & 0.015 & 46.6 & $0.012-$ \\
& 0.005 & & & 0.055 \\
Spleen & $0.137 \pm$ & 0.052 & 37.6 & $0.064-$ \\
& 0.02 & & & 0.238 \\
Liver & $0.147 \pm$ & 0.089 & 60.5 & $0.057-$ \\
& 0.03 & & & 0.318 \\
\hline
\end{tabular}


Regarding the level of $\mathrm{Pb}$ accumulation in organs and tissues, the ranged row is presented as follows: liver $<$ spleen $<$ muscle $<$ testicles in the ratio $4.7: 4.4: 1.2: 1$. $\mathrm{Pb}$ level in muscles positively correlated to isoleucine, the correlation to $\mathrm{K}, \mathrm{Na}$ and $\mathrm{Mg}$ was less. It was found that $\mathrm{Pb}$ content correlated negatively to vitamins $\mathrm{E} . \mathrm{B}_{1} . \mathrm{B}_{2} . \mathrm{B}_{6}$. Thus, $\mathrm{Pb}$ incorporated in the organism decreases the level of a number of vitamins, which indicates the negative impact of lead on the organism. In turn, the organism responds to the increased entrance of lead by the increased level of isoleucine. It can be suggested that the amino acid isoleucine is one of the factors that somehow neutralizes the negative effect of lead on the organism.

$\mathrm{Pb}$ level in testicles of bull-calves is characterized by somewhat lower phenotypic variability as compared to muscle and liver. The capability to accumulate lead in testicles is less differentiated in the animals as well (1:4.6). High positive correlations to magnesium and phosphorus as well as to potassium, sodium, lead and copper are revealed. Positive correlation of lead to arginine and serine is marked. Negative correlation is observed only to oxyproline and tryptophan, less expressed relation is to cadmium ( $\mathrm{r}=-0.30)$. Consequently, lead is associated with accumulation of some chemical elements. The correlation of lead to phosphorus and manganese should be focused on, that may testify to the indirect involvement of lead in the growth and functioning of bone tissue. In turn, the negative correlation of lead to oxyproline and tryptophan might testify to the toxic effect on the organism.

The least amount of lead is accumulated in testicles. Evolutionarily, to preserve a species, reproduction organs, in the first place, must be protected against the effect of negative factors.

In spleen, the phenotypic variability of $\mathrm{Pb}$ concentration is relatively lower. Regarding the spleen, the animals are least differentiated for the capacity to accumulate lead (1:3.7). It is the spleen where high correlations of lead to cadmium and copper are detected. This is explained by the immune function of spleen to trap and process harmful substances and purify blood from different foreign agents [3. 8]. It is in the spleen where high relation of $\mathrm{Pb}$ concentration to sodium and the mean one to potassium are revealed. Perhaps, there is lead-mediated involvement in the performance of $\mathrm{Na}^{+}$$\mathrm{K}^{+}$pump that provide regulation of cellular exchange of different metabolites and that of osmotic and water exchange.

Table 2. Correlation of $\mathrm{Pb}$ level in organs and tissues to some amino acids. vitamins and chemical elements

\begin{tabular}{|l|c|c|c|}
\hline \multicolumn{1}{|c|}{ Muscles } & $\mathbf{r}$ & Testicles & $\mathbf{r}$ \\
\hline $\begin{array}{l}\text { Lead- } \\
\text { Isoleucine }\end{array}$ & 0.411 & $\begin{array}{c}\text { Lead- } \\
\text { Tryptophan }\end{array}$ & -0.585 \\
\hline -Vitamin E & -0.357 & -Oxyprolin & -0.510 \\
\hline -Vitamin $\mathrm{B}_{1}$ & -0.353 & -Serine & 0.379 \\
\hline - Vitamin $\mathrm{B}_{2}$ & -0.329 & -Arginine & 0.436 \\
\hline - Vitamin $\mathrm{B}_{6}$ & -0.387 & $\begin{array}{c}\text { - Vitamin } \\
\mathrm{B}_{1}\end{array}$ & -0.215 \\
\hline - Vitamin & -0.143 & - Vitamin & -0.252 \\
\hline
\end{tabular}

\begin{tabular}{|l|c|c|c|}
$\mathrm{B}_{12}$ & & $\mathrm{~B}_{1}$ & \\
\hline -Calcium & -0.400 & $\begin{array}{c}- \text { Vitamin } \\
\mathrm{B}_{6}\end{array}$ & -0.249 \\
\hline -Iron & -0.350 & $\begin{array}{c}- \text { Vitamin } \\
\mathrm{B}_{12}\end{array}$ & -0.253 \\
\hline \multicolumn{1}{|c|}{ Spleen } & & -Phosphorus & 0.526 \\
\hline $\begin{array}{l}\text { Lead- } \\
\text { Potassium }\end{array}$ & 0.520 & -Potassium & 0.398 \\
\hline -Sodium & 0.763 & -Sodium & 0.338 \\
\hline -Manganese & 0.452 & -Manganese & 0.559 \\
\hline -Copper & 0.686 & -Copper & 0.358 \\
\hline -Cadmium & 0.799 & -Lead & 0.361 \\
\hline \multicolumn{1}{|c|}{ Liver } & & -Cadmium & -0.304 \\
\hline $\begin{array}{l}\text { Lead- } \\
\text { Sodium }\end{array}$ & 0.466 & & \\
\hline
\end{tabular}

In liver, higher phenotypic variability and different capacity to accumulate lead are observed in individual animals (in the ratio 1:5.8). A single important correlation of lead to sodium is found in the liver. This testifies to the role of lead in absorbing the sodium, i.e., the superfluous entering of the lead can cause the increased concentration of sodium that in turn, can result in the accumulation of excessive liquid in the organism. As a result, blood pressure goes up causing the risk of cardio-vascular diseases. Eventually, high permanent level of sodium in the organism leads to edemas, hypertension and kidney diseases.

There have been revealed different-in-value correlations of lead content in muscles and liver to the level of a series of biochemical indexes in blood serum (Table 3). Hence, a series of biochemical parameters in blood serum can indicate the content of lead in muscles and liver.

The data on estimating the content of heavy metals in the organs and tissues of Hereford bull-calves testify to the different capability of animals to accumulate lead. The level of lead in liver and muscles is characterized by high phenotypic variability. In muscles, correlation of $\mathrm{Pb}$ level is associated with isoleucine, which can testify to the responsive and defensive reaction of the organism.

Table 3. Correlation of $\mathrm{Pb}$ level in muscles and liver to some biochemical indexes of blood serum

\begin{tabular}{|c|c|}
\hline Muscles-blood serum & r \\
\hline $\mathrm{Pb}$-Aspartate aminotransferase & $0.590 \pm 0.285$ \\
\hline -High density lipoproteins & $0.635 \pm 0.292$ \\
\hline - Alkaline phosphatase & $0.845 \pm 0.270$ \\
\hline -Glucose & $-0.643 \pm 0.271$ \\
\hline -Lactic acid & $-0.623 \pm 0.296$ \\
\hline -Calcium & $0.681 \pm 0.259$ \\
\hline Liver-blood serum & \\
\hline $\mathrm{Pb}$ - Alkaline phosphatase & $0.845 \pm 0.268$ \\
\hline -Lactic acid & $-0.623 \pm 0.296$ \\
\hline -Amylase & $-0.534 \pm 0.320$ \\
\hline
\end{tabular}

There is negative correlation of lead to oxyproline and tryptophan in testicles, which explains the toxic influence of lead on animal organism. In muscles and testicles, negative correlation of lead to the vitamins of B 
group is found that is the consequence of the negative effect of lead on the vitamins absorption and exchange. High correlation of lead to other heavy metals is identified in spleen. There exists lead to sodium relation in all the organs and tissues, particular considerable are correlations in spleen and liver; the lead might influence sodium exchange in the organism.

\section{Conclusions}

Selectivity of lead accumulation in organs and tissues of cattle is revealed. The highest concentrations of the element were found in liver and spleen. The increased level of lead in muscles and spleen decreases their level of group B vitamins. In testicles, the concentrations of lead negatively correlate to those of amino acids, tryptophan and oxyproline. The increased content of lead in spleen results in the increased concentration of heavy metals, such as cadmium and copper. A complex of some biochemical blood serum indexes can be lifetime indicators of lead accumulation intensity in muscles and liver.

\section{References}

1. Ilyin V.B., Syso A.I. Microelements and heavy metals in the soils and plants of Novosibirsk region. Novosibirsk: Publishing house SB RAS, 2011. - pp. 229.

2. Kalnitsky B.D. Mineral substances in livestock feeding. -L.: Agropromizdat, 1985. -pp. 207.

3. Jin, A., Herzman, C. , Peck, S.H. Blood lead levels in children aged 24 to 36 months in Vancouver // Can. Med. Assoc. J. - 1995. - V. 152. - № 7. - pp. 1077-1086.

4. Szymozak, J., Ilow, R., Regulska-Ilow, B. Level of cadmium and lead in vegetables, fruit, cereal and soil from arials differing in the degree of industrial pollution and from greenhouses // Rocz. Panstw. Zakl. Hig. - 1993. - V. 44. № 4. - pp. 331-346.

5. Abdel-Mageed, A., Oehme, F.W. A review on biochemical roles, toxicity and interactions of zinc, copper and iron // Vet. Human. Toxicol. - 1990. №32(5). - pp. 456-458.

6. Skalny A.V., Rudakov I.A. Bioelements in medicine. M.: Mir, 2004. -pp. 272.

7. Glaister, J.R. Principles of Toxicological Pathology. London and Philadelphia: Taylor \& Francis, 1986. - pp. 213.

8. Avtsyn P.A., Zhavoronkov A.A., Rish M.A., Strochkova L.S. Microelementoses of human. -M.: Medicine, 1991. -pp. 496

9. Chysyma R.B., Patrashkov S.A., Petukhov V.L. The content of heavy metals in the hair of animals from different ecological areas. Siberian news of agricultural science (“Sibirsky Vestnik”), 2004. -№1. -pp.75-76.

10. Fowllr B.A. Molecular and cell biology of lead / In: Cellular and molecular biology of metals. ed. By Zalups R.K., Koropatnick. Us: CRC Press Taylor \& Francis Group, 2010/ - pp. 113-126. 